\title{
PENGEMBANGAN E-MODUL PEMBELAJARAN ADMINISTRASI SERVER KELAS XI TKJ DI SMK TI BALI GLOBAL SINGARAJA
}

\author{
Ni Putu Intan Pradnya Parmita ${ }^{1}$, Ketut Agustini ${ }^{2}$, Gede Saindra Santyadiputra $^{3}$ \\ 1,2,3 Jurusan Pendidikan Teknik Informatika, Fakultas Teknik dan Kejuruan \\ Universitas Pendidikan Ganesha \\ Singaraja, Bali

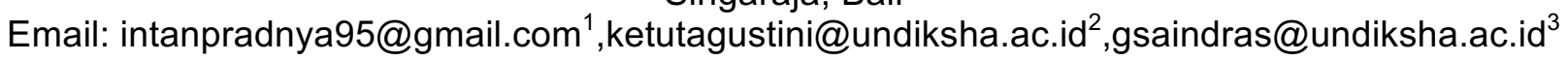

\begin{abstract}
Abstrak- Tujuan penelitian ini adalah: (1) Untuk menghasilkan rancangan dan merealisasikan Pengembangan E-Modul Pembelajaran Administrasi Server Kelas X TKJ di SMK TI Bali Global Singaraja, (2) Untuk mengetahui respon guru dan siswa terhadap Pengembangan E-Modul Pembelajaran Administrasi Server Kelas X TKJ di SMK TI Bali Global Singaraja. Jenis penelitian yang digunakan dalam penelitian ini adalah penelitian dan pengembangan (Research and Development) dengan model pengembangan PLOMP. Subjek penelitian ini yaitu siswa kelas XI TKJ di SMK TI Bali Global Singaraja tahun ajaran 2017/2018. Untuk mengetahui respon guru dan siswa terhadap emodul administrasi server diperoleh dengan menggunakan metode angket Hasil penelitian menunjukkan bahwa: (1) Hasil rancangan dan realisasi e-modul berbasis model pembelajaran discovery learning pada mata pelajaran administrasi server untuk siswa kelas XI TKJ di SMK TI Bali Global Singaraja dinyatakan berhasil diterapkan berdasarkan beberapa uji yang dilakukan. (2) Hasil analisis data respon guru menunjukkan bahwa, didapatkan rata-rata skor respon sebesar 43 , jika dikonversikan ke dalam tabel penggolongan respon maka termasuk pada kategori positif. Sedangkan untuk respon siswa terhadap pengembangan emodul didapatkan rata-rata skor respon sebesar 64,50, jika dikonversikan ke dalam tabel penggolongan respon siswa termasuk pada kategori positif
\end{abstract}

Kata Kunci: E-Modul, Administrasi Server, Discovery Learning

Abstract- The aims of this research are: (1) To develop and to realitation e-modul discovery learning teaching model toward $x$ grade students of Computer technique and Network at SMK TI Bali Global Singaraja, (2) To know both students and teachers response toward the development of emodul discovery learning teaching model in server administration subject toward $x$ grade students of Computer technique and Network at SMK TI Bali Global Singaraja. The design of this research was $R \& D$ (research and development) research design accompanied with the development model of PLOMP. The subject of this research was all $X$ grade students of Computer technique and Network department SMK TI Bali Global Singaraja academic year 2017/2018. In order to know both teachers and students response toward the e-modul server administration, the researcher used questionnaire. This research shows that: (1) the development of e-modul discovery learning teaching model in videography subject toward $x$ grade students of Computer technique and Network at SMK TI Bali Global Singaraja have been successfully realitation looking at several tests have been done by the researcher. (2) Based on the analysis of the data of teacher's response, it shows the mean score of 43 , if this converts into table of response categorization, it belongs to positive category. Furthermore, based on the analysis of the data of students' response, on the other hand, shows the mean score of 64,50 . If it is converted into table of response categorization, it belongs to positive category.

Keywords: E-Modul, Server Administration, Discovery Learning 


\section{PENDAHULUAN}

Seiring dengan perubahan kurikulum pada tahun 2013, yang mengubah Kurikulum Tingkat Satuan Pendidikan (KTSP) menjadi Kurikulum 2013 membawa perubahan besar pada dunia pendidikan. Salah satunya yaitu pelaksanaan pembelajaran yang harus didukung dengan adanya media pembelajaran berbasis teknologi. Berdasarkan Peraturan Pemerintah No.17 (2010) menyatakan bahwa: "Dalam menyelenggarakan dan mengelola pendidikan, satuan dan/atau program pendidikan mengembangkan dan melaksanakan sistem informasi pendidikan berbasis teknologi informasi dan komunikasi". Hal ini menunjukkan bahwa penggunaan media pembelajaran sebagai teknologi informasi dalam proses pembelajaran sudah menjadi kebutuhan sekaligus tuntutan di era globalisasi sehingga dalam hal ini dapat menciptakan kualitas manusia yang tidak hanya bergantung melalui transfer ilmu secara verbal.

Namun kenyataannya setelah dilakukan observasi, wawancara dan penyebaran angket di kelas X TKJ SMK TI Bali Global Singaraja pada mata pelajaran Administrasi Server, diperoleh informasi bahwa media pembelajaran yang digunakan belum sesuai dengan tuntutan kemajuan arus informasi yang memanfaatkan teknologi informasi dan komunikasi sebagai sistem informasi pendidikan. Media yang digunakan saat proses pembelajaran berupa power point yakni materi yang tersampaikan hanya inti dari materi tersebut. Hal ini berbanding terbalik dengan Peraturan Pemerintah No.17 tahun 2010 pasal 59, karena dengan hadirnya peraturan tersebut dapat menyempurnakan akses sumber pembelajaran kepada pendidik, tenaga kependidikan, dan peserta didik. Bahkan sekolah telah memiliki fasilitas seperti wifi yang tersedia di beberapa titik di wilayah sekolah yang memungkinkan pembelajaran berbantu media pembelajaran. Secara umum sekolah tersebut memiliki SDM yang baik dalam hal ini guru memiliki kemampuan dalam bidang teknologi, informasi dan komunikasi (TIK). SDM yang didukung dengan fasilitas yang ada sebenarnya memiliki kemampuan mengembangan media pembelajaran. Hal ini dikarenakan guru memiliki jadwal mengajar yang padat, mengejar targer kurikulum serta guru diwajibkan membuat persiapan mengajar. Selain itu siswa juga masih terlalu bergantung pada materi yang diberikan oleh guru di kelas serta siswa kurang mampu mencari dan menemukan solusi secara mandiri sesuai dengan tuntutan Kurikulum 2013. Permasalahan ini disebabkan oleh ketidaktahuan siswa mencari sumber belajar yang tepat dan sumber belajar yang tersusun secara terstruktur. Dalam proses pembelajaran guru menggunakan model pembelajaran konvensional/ceramah dimana sistem pembelajaran konvensional kurang fleksibel dalam mengakomodasi perkembangan materi kompetensi karena pendidik harus intensif menyesuaikan materi pelajaran dengan perkembangan teknologi baru (Agustini, 2013). Sebagian besar siswa kelas $X$ TKJ menuturkan bahwa mereka perlu media pembelajaran dengan materi yang dipaparkan tidak hanya berupa teks namun juga berupa gambar dan video animasi 2 dimensi yang menggambarkan konsep dari meteri-materi yang masih berupa abstrak menjadi lebih konkret sehingga menghasilkan media pembelajaran yang valid, praktis dan efektif yang dapat meningkatkan mutu serta kualitas pembelajaran.

Untuk mencapai proses ini, dibutuhkan suatu media pembelajaran yang dikemas dengan model pembelajaran sehingga dapat mengoptimalkan proses penyerapan materi. Melalui media pembelajaran, peserta didik mampu memperoleh pesan dan informasi sehingga membentuk pengetahuan baru pada siswa. Pemilihan media sebagai sumber belajar mandiri dapat memperkaya pengalaman belajar dan membantu kesiapan siswa untuk mendapatkan materi yang akan diajarkan dipertemuan berikutnya. Salah satu media yang memenuhi kriteria sebagai media pembelajaran mandiri adalah modul elektronik. Modul elektronik dapat didefinisikan sebagai sebuah bentuk penyajian bahan belajar mandiri yang disusun secara sistematis ke dalam unit pembelajaran terkecil untuk mencapai tujuan pembelajaran tertentu, yang disajikan dalam format elektronik yang setiap kegiatan pembelajaran di dalamnya 
dihubungkan dengan link - link sebagai navigasi yang membuat peserta didik menjadi interaktif dengan program, dilengkapi dengan penyajian video tutorial, animasi dan audio untuk memperkaya pengalaman belajar (Gunadharma, 2011). Modul elektronik atau yang biasa disebut dengan e-modul merupakan inovasi terbaru dari modul cetak, sehingga modul elektronik ini dapat diakses dengan bantuan komputer yang sudah terintregrasi dengan perangkat lunak yang mendukung pengaksesan e-modul. Kelebihan emodul dibandingkan dengan modul cetak adalah sifatnya yang interaktif memudahkan dalam navigasi, dapat menampilkan atau memuat gambar, audio, video dan animasi serta dilengkapi tes formatif yang memungkinkan umpan balik otomatis dengan segera. Mertasari (2010) menambahkan bahwa penggunaan emodul akan menjamin kontrol siswa serta fleksibilitas. Pengembangan e-modul dapat dikembangkan dengan berbagai model pembelajaran. Pada penelitian ini digunakan model pembelajaran yang sesuai dengan kurikulum 2013 salah satunya yaitu model pembelajaran Discovery Learning. Model pembelajaran discovery learning didefinisikan sebagai proses pembelajaran yang terjadi bila materi pembelajaran tidak disajikan dalam bentuk finalnya, tetapi diharapkan siswa mengorganisasi sendiri (Kurniasih, 2014). Pernyataan lebih lanjut dikemukakan oleh Hosnan (2014) bahwa discovery learning adalah suatu model untuk mengembangkan cara belajar aktif dengan menemukan sendiri, menyelidiki sendiri, maka hasil yang diperoleh akan setia dan tahan lama dalam ingatan. Melalui belajar penemuan, siswa juga bisa belajar berpikir analisis dan mencoba memecahkan sendiri masalah yang dihadapi. Pada penelitian ini modul elektronik yang dikemas dengan model pembelajaran discovery learning akan disusun dengan bantuan platform inovatif yaitu Schoology. Schoology merupakan situs yang menggabungkan antara Social Learning Networks (SLNs) dan learning management system (LMS) untuk K-12 sekolah, lembaga pendidikan tinggi, dan perusahaan yang memungkinkan pengguna untuk membuat, mengelola, dan berbagi konten dan sumber daya.
Schoology adalah sebuah layanan gratis yang menggunakan konsep pengelolaan pembelajaran sosial yang dikhususkan untuk membangun lingkungan belajar online yang aman untuk berbagi informasi serta fitur-fitur atau konten pendidikan baik berbentuk tulisan, file dan link yang dapat dibagikan baik guru maupun siswa. Maka dari itu dengan adanya Schoology siswa dapat belajar secara online, berkolaborasi dengan rekan-rekan mereka dan dapat belajar secara mandiri sesuai dengan tujuan model pembelajaran discovery learning, selain itu dengan menggunakan Schoology proses pembelajaran akan lebih interaktif, karena dengan adanya Schoology dapat menyisipkan suatu bahan ajar tidak hanya dalam bentuk teks saja, bisa dalam bentuk animasi, audio maupun video yang dapat membuat siswa menjadi lebih tertarik dalam mempelajarinya sesuai dengan kebutuhan mata pelajaran Administrasi Server. Adapun kelebihan dari Schoology diantaranya stay conneted, extend class time, manage on the go serta leverage iOS and android device.

Berdasarkan penelitian sebelumnya terkait dengan penelitian e-modul, didapatkan beberapa hasil penelitian yang relevan dengan penelitian pengembangan e-modul, yaitu Baskara (2017) dengan Pengembangan E-Modul Berbasis Model Pembelajaran Discovery Learning Pada Mata Pelajaran "Sistem Komputer" Untuk Siswa Kelas $X$ Multimedia SMK Negeri 3 Singaraja.dinyatakan layak, ditinjau dari komponen media, materi serta proses pembelajarannya. Sedangkan menurut Ananda (2014) terkait penelitian pengembangan berbasis Schoology menyatakan bahwa penggunaan elearning berbasis schoology pada mata pelajaran IPA kelas VII di SMP Negeri 1 Seririt dinyatakan efektif untuk meningkatkan hasil belajar pada mata pelajaran tersebut. Hal ini dibuktikan berdasarkan hasil uji dari nilai rata-rata hasil belajar siswa.

Berdasarkan uraian di atas, maka perlu dikembangkan suatu bahan ajar dalam hal ini berupa modul elektronik berbasis model pembelajaran discovery learning. Adanya modul yang disajikan dalam bentuk digital ini diharapkan mampu membantu proses berpikir siswa untuk 
memahami konsep administrasi server secara menyeluruh melalui kegiatan mengamati fakta, menanya, mengumpulkan informasi, mengasosiasi dan mengkomunikasikan. Terkait hal ini, peneliti melakukan pengembangan emodul dalam penelitian dengan judul "Pengembangan E-Modul Pembelajaran Administrasi Server Kelas X TKJ Di SMK TI Bali Global Singaraja".

\section{KAJIAN TEORI}

\section{A. Mata Pelajaran}

Mata pelajaran Administrasi Server merupakan bagian dari kelompok pelajaran produktif yang ada di kompetensi keahlian Teknik Komputer dan Jaringan yang menerapkan model pembelajaran dengan proposisi pembelajaran $60 \%$ teori dan $40 \%$ praktik. Administrasi server mempelajari tentang pengontrolan atau pengelolaan akses terhadap jaringan dan sumber daya yang terdapat di dalamnya. Administrasi itu sendiri merupakan suatu hal yang berhubungan dengan pengelolaan, pemberian jasa atau bantuan, dan pelayanan sedangkan server merupakan suatu bagian terpenting dari sebuah jaringan yang bertugas untuk menyediakan layanan yang dibutuhkan oleh client

Modul Ajar Modul ajar adalah bahan ajar yang disusun secara sistematis dan menarik yang mencakup isi materi, metode dan evaluasi yang dapat digunakan secara mandiri untuk mencapai kompetensi yang diharapkan (Anwar, 2010). (Vembrianto, 1985), menyatakan bahwa suatu modul ajar adalah suatu paket pengajaran yang memuat satu unit konsep daripada bahan pelajaran. Pengajaran modul merupakan usaha penyelanggaraan pengajaran individual yang memungkinkan siswa menguasai satu unit bahan pelajaran sebelum dia beralih kepada unit berikutnya. Berdasarkan beberapa pengertian modul di atas maka dapat disimpulkan bahwa modul ajar adalah salah satu bentuk bahan ajar yang dikemas secara sistematis dan menarik sehingga mudah untuk dipelajari secara mandiri.

\section{B. Model pembelajaran discovery learning.}

$\begin{array}{crrr}\text { Belajar } & \text { penemuan } & \text { (discovery } & \text { learning) } \\ \text { merupakan } & \text { salah } & \text { satu } & \text { model }\end{array}$
pembelajaran/belajar kognitif yang dikembangkan oleh Bruner. Menurut Bruner, belajar bermakna hanya dapat terjadi melalui belajar penemuan yang merupakan proses belajar. Guru harus menciptakan situasi belajar yang problematis, menstimulus siswa dengan pertanyaanpertanyaan, mencari jawaban sendiri dan melakukan eksperimen. Bentuk lain dari belajar penemuan adalah guru menyajikan contoh-contoh dan si pebelajar bekerja dengan contoh tersebut sampai dapat menemukan sendiri dan melakukan eksperiman. Salah satu model belajar penemuan yang diterapkan di Indonesia adalah konsep Cara Belajar Siswa Aktif (CBSA). Di dalam model pembelajaran discovery learning, tidak semua yang harus dipelajari dipresentasikan dalam bentuk yang final, beberapa bagian harus dicari, diidentifikasikan oleh pelajar sendiri. Kemudian informasi ini diintegrasikan ke dalam struktur kognitif yang telah ada, disusun kembali, diubah, untuk menghasilkan struktur kognitif yang baru. Menurut Kurniasih (2014) mengungkapkan bahwa discovery learning adalah menemukan konsep melalui serangkaian data atau informasi yang diperoleh melalui pengamatan atau percobaan. Langkah-langkah Persiapan Model discovery learning menurut (Syah, 2005) sebagai berikut: 1) Menentukan tujuan pembelajaran, 2) Melakukan identifikasi karakteristik siswa, 3) Memilih materi pelajaran, 4) Menentukan topiktopik yang harus dipelajari siswa secara induktif, 5) Mengembangkan bahan-bahan belajar yang berupa contoh-contoh, ilustrasi, tugas dan sebagainya untuk dipelajari siswa. Prosedur aplikasi model discovery learning menurut (Syah, 2005) sebagai berikut: 1) Stimulation (Stimulasi/Pemberian Rangsangan), 2) Problem Statement (Pernyataan/ Identifikasi Masalah), 3) Data Collection (Pengumpulan Data), 4) Data Processing 4 Title goes here (Pengolahan Data). 5) Verification (Pembuktian), 6) Generalization (Menarik Kesimpulan/Generalisasi). 


\section{Modul Ajar}

Modul ajar adalah bahan ajar yang disusun secara sistematis dan menarik yang mencakup isi materi, metode dan evaluasi yang dapat digunakan secara mandiri untuk mencapai kompetensi yang diharapkan (Anwar, 2010). (Vembrianto, 1985), menyatakan bahwa suatu modul ajar adalah suatu paket pengajaran yang memuat satu unit konsep daripada bahan pelajaran. Pengajaran modul merupakan usaha penyelanggaraan pengajaran individual yang memungkinkan siswa menguasai satu unit bahan pelajaran sebelum dia beralih kepada unit berikutnya. Berdasarkan beberapa pengertian modul di atas maka dapat disimpulkan bahwa modul ajar adalah salah satu bentuk bahan ajar yang dikemas secara sistematis dan menarik sehingga mudah untuk dipelajari secara mandiri.

\section{E-Modul (Modul Elektronik)}

Modul elektronik merupakan versi elektronik dari sebuah modul yang sudah dicetak yang dapat dibaca pada komputer dan dirancang dengan software yang diperlukan. E-modul merupakan alat atau sarana pembelajaran yang berisi materi, metode, batasan-batasan dan Author surnames go here 3 cara mengevaluasi yang dirancang secara sistematis dan menarik untuk mencapai kompetensi yang diharapkan sesuai dengan tingkat kompleksitasnya secara elektronik. Menurut (Gunadharma, 2011) modul elektronik dapat didefinisikan sebagai sebuah bentuk penyajian bahan belajar mandiri yang disusun secara sistematis ke dalam unit pembelajaran terkecil untuk mencapai tujuan pembelajaran tertentu, yang disajikan dalam format elektronik, dimana setiap kegiatan pembelajaran di dalamnya dihubungkan dengan link - link sebagai navigasi yang membuat peserta didik menjadi interaktif dengan program, dilengkapi dengan penyajian video tutorial, animasi dan audio untuk memperkaya pengalaman belajar. Modul elektronik yang dapat diakses oleh siswa mempunyai manfaat dan karakteristik yang berbeda beda. Jika ditinjau dari manfaatnya media elektronik sendiri dapat menjadikan proses pembelajaraan lebih menarik, interaktif, dapat dilakukan kapan dan dimana saja dapat meningkatkan kualitas pembelajaran (Cecep \& Bambang, 2013).

\section{E. Schoology}

Schoology merupakan salah satu platform inovatif yang dibangun berdasarkan inspirasi dari media sosial facebook dengan tujuan untuk kepentingan pendidikan. Platform ini dikembangkan pada tahun 2009 di New York. Platform Schoology dirancang Oleh Jeremy Friedman, Ryan Hwang dan Tim Trinidad. Komunitas Global Schoology diadopsi dari 12 juta orang di seluruh 130 negara di dunia. Schoology adalah Learning Managemen System (LMS) untuk K-12 sekolah, lembaga pendidikan tinggi, dan perusahaan yang memungkinkan pengguna untuk membuat, mengelola, dan berbagi konten dan sumber daya. Schoology juga dikenal sebagai Content Management System (CMS) atau lingkungan belajar virtual (VLE), platform berbasis cloud menyediakan alat untuk mengelola setiap kelas atau lingkungan blended learning. Schoology merupakan media dimana orang tua, siswa dan guru saling terhubung sama lain. Dalam sistem, orang tua akan mengetahui penilaian dalam hal ini yaitu kemajuan anakanaknya dalam proses pembelajaran yang direkam oleh guru.

\section{F. Kerangka Berpikir}

Berdasarkan latar belakang masalah dan kajian teori yang telah dipaparkan bahwa teknologi komunikasi dan informasi yang berkembang di era globalisasi ini, dapat dimanfaatkan untuk pembelajaran di sekolah. Untuk itu diperlukanlah sebuah media pembelajaran untuk menunjang pembelajaran tersebut. Salah satunya yaitu pembelajaran Administrasi Server. Pelajaran administrasi server mempelajari tentang pengontrolan atau pengelolaan akses terhadap jaringan dan sumber daya yang terdapat di dalamnya.Harapannya solusi yang ditawarkan mampu meminimalisir atau mengurangi permasalahan yang terjadi dan memberikan dampak positif terhadap proses pembelajaran sehingga apa yang menjadi tujuan utama dalam pembelajaran bisa tercapai dengan optimal. Salah satu solusinya adalah media pembelajaran yang valid, praktis dan efektif yang dapat 
meningkatkan mutu serta kualitas pembelajaran. Hal ini yang dimaksud adalah pengembangan emodul berbasis model pembelajaran Discovery Learning. Emodul berbasis model Discovery Learning yang dikembangkan sebagai salah satu solusi pemecahan masalah pada kegiatan pembelajaran sehingga diharapkan dapat bermanfaatuntuk peserta didik, guru dan sekolah dalam meningkatkan keberhasilan proses kegiatan pembelajaran serta dapat meningkatkan mutu dan kualitas pembelajaran.

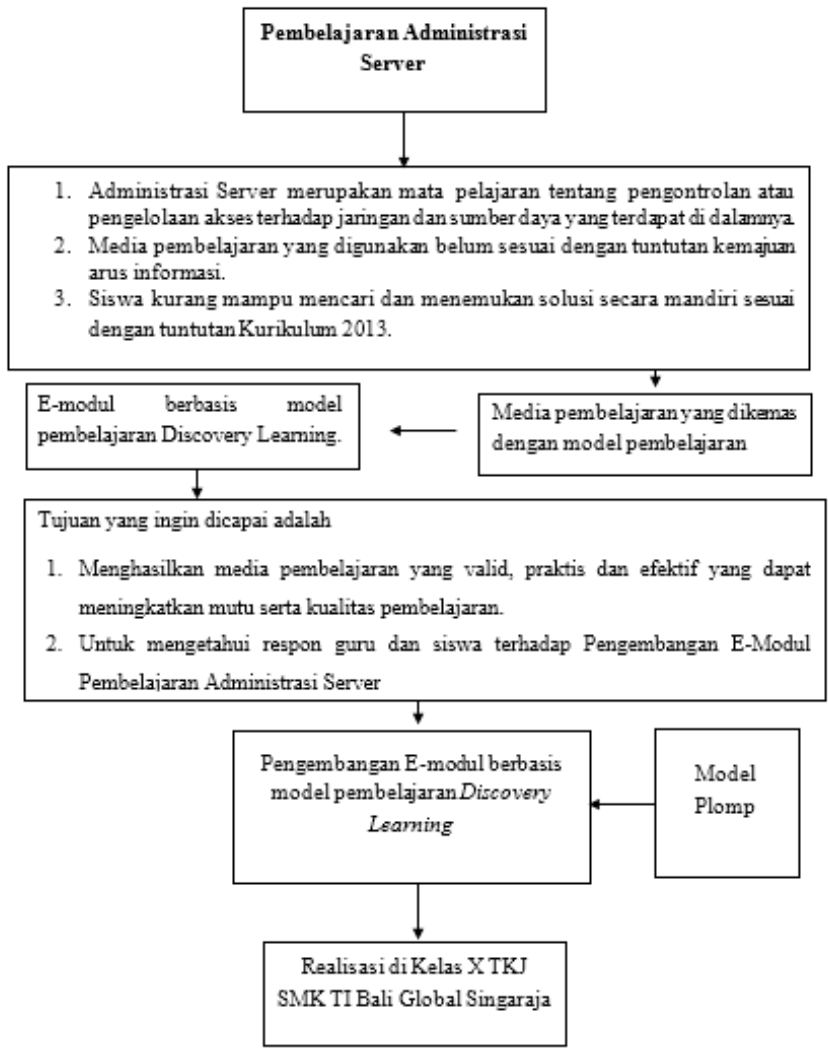

Gambar 1 Kerangka Berpikir Pengembangan EModul

\section{METODOLOGI}

Penelitian pada Pengembangan E-modul Berbasis Model Discovery Learning Mata Pelajaran Administrasi Server menggunakan jenis penelitian Research and Development. Research and Development ( $R$ \& $D$ ) adalah proses yang digunakan untuk mengembangkan dan memvalidasi produk pendidikan. Penelitian ini menggunakan desain pengembangan model
Plomp. Desain pengembangan model Plomp merupakan salah satu model desain sistematik dan tepat digunakan pada penelitian pengembangan pendidikan. Model umum untuk memecahkan masalah bidang pendidikan yang dikemukakan (Plomp, 1997) yang selanjutnya disebut model Plomp, seperti terlihat pada Gambar 2.

\section{Teknik Pengumpulan Data}

Data yang dikumpulkan untuk dianalisis bersifat kualitatif dan kuantitatif dalam penelitian ini, yaitu meliputi informasi sumber belajar, kevalidan e-modul dan respon siswa dan guru terhadap e-modul yang akan dikembangkan. Teknik pengumpulan data dapat dilihat pada Tabel 1.

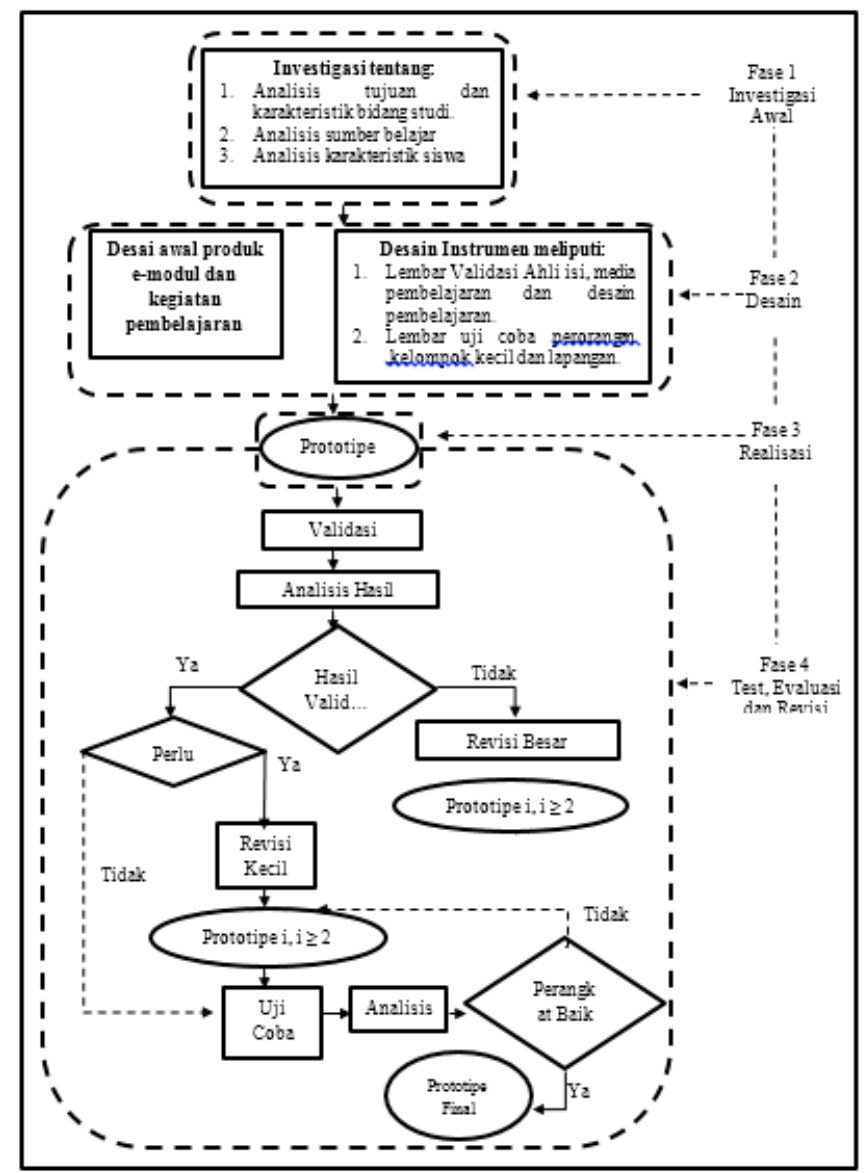

Gambar 2 Diagram Alur Fase Pengembangan oleh Tjeerd Plomp yang diadaptasi dari

(Khabibah,2006) 


\begin{tabular}{|l|l|l|l|}
\hline No & \multicolumn{1}{|c|}{$\begin{array}{c}\text { Jenis } \\
\text { Data }\end{array}$} & Metode & \multicolumn{1}{|c|}{ Sumber Data } \\
\hline 1 & $\begin{array}{l}\text { Informasi } \\
\text { tentang } \\
\text { sumber } \\
\text { belajar } \\
\text { ara }\end{array}$ & $\begin{array}{l}\text { Wawanc } \\
\text { Karakteris } \\
\text { tik } \\
\text { peserta } \\
\text { didik }\end{array}$ & $\begin{array}{l}\text { Guru } \\
\text { Pelajaran } \\
\text { Administrasi Server }\end{array}$ \\
\hline 3 & $\begin{array}{l}\text { Kevalidan } \\
\text { e-modul }\end{array}$ & $\begin{array}{l}\text { Angket } \\
\text { Xeserta didik kelas } \\
\text { Bali dKJ SMK TI } \\
\text { Singaraja Global }\end{array}$ \\
\hline 4 & $\begin{array}{l}\text { Respon } \\
\text { guru dan } \\
\text { peserta } \\
\text { didik }\end{array}$ & $\begin{array}{l}\text { Angembelajaran, ahli } \\
\text { desain } \\
\text { pembelajaran, dan } \\
\text { ahli } \\
\text { pembelajaran media }\end{array}$ \\
\hline
\end{tabular}

Pada kegiatan observasi guna mendapat informasi sumber belajar dan karakteristik pembelajar, digunakan jenis metode wawancara serta angket tertutup dan terbuka. Melalui metode wawancara dan angket ini peneliti mengetahui masalah yang terjadi ketika pembelajaran berlangsung terkait sumber belajar, materi, media, dan ketertarikan serta karakteristik siswa dalam pembelajaran administrasi server.

Metode angket digunakan dalam kegiatan review dari ahli isi bidang studi, ahli desain pembelajaran, ahli media pembelajaran, uji coba perorangan, uji coba kelompok kecil, dan uji coba lapangan. Uji para ahli terdiri dari dua pilihan yaitu Sesuai dan Tidak Sesuai, sedangkan untuk uji coba perorangan, uji coba kelompok kecil, uji coba lapangan, dan uji respon terdiri dari lima pilihan, yaitu Sangat Setuju (SS), Setuju (S),
Kurang Setuju (KS), Tidak Setuju (TS), dan Sangat Tidak Setuju (STS). Untuk skor pada angket uji coba dapat dilihat pada Tabel 2

\begin{tabular}{|l|c|c|}
\hline \multicolumn{1}{|c|}{ Alternatif } & $\begin{array}{c}\text { Skor } \\
\text { Pernyataan } \\
\text { Positif }\end{array}$ & $\begin{array}{c}\text { Skor } \\
\text { Pernyataan } \\
\text { Negatif }\end{array}$ \\
\hline $\begin{array}{l}\text { Sangat Setuju } \\
\text { (SS) }\end{array}$ & 5 & 1 \\
\hline Setuju (S) & 4 & 2 \\
\hline $\begin{array}{l}\text { Kurang Setuju } \\
\text { (KS) }\end{array}$ & 3 & 3 \\
\hline Tidak Setuju (TS) & 2 & 4 \\
\hline $\begin{array}{l}\text { Sangat Tidak } \\
\text { Setuju (SKS) }\end{array}$ & 1 & 5 \\
\hline
\end{tabular}

\section{G. TEKNIK ANALISIS DATA}

Analisis data pada penelitian pengembangan ini bertujuan untuk menjawab rumusan masalah dalam kesimpulan. Berikut ini merupakan teknik analisis data yang digunakan oleh peneliti, diantaranya yaitu :

1. Analisis data kevalidan Modul Ajar Analisis data kevalidan e-modul dimaksudkan untuk mengetahui sejauh mana e-modul yang telah dibuat memenuhi kriteria berdasarkan penilaian validator yang ditunjuk dengan menggunakan lembar validasi ahli, hasil validasi ahli menjadi dasar dan pertimbangan dalam melakukan revisi

2. Analisis data respon guru dan siswa Analisis data respon guru dan siswa dimaksudkan untuk mengetahui bagaimana respon guru dan siswa terhadap e-modul yang dikembangkan

\section{H. ANALISIS DATA KEVALIDAN E-MODUL}

Validasi e-modul diuji oleh ahli isi, ahli desain, ahli media, uji perorangan dan uji kelompok kecil, menganalisis respon guru dan siswa terhadap pengembangan e-modul diuraikan sebagai berikut.

1. Validasi Ahli Isi

Validasi isi dapat diperoleh melalui ahli isi. Validasi ini bertujuan untuk mengetahui isi yang terkandung di dalam e-modul apakah 
sudah sesuai dengan konsep pengetahuan atau indikator yang ingin dicapai. Konsep pengetahuan atau indikator yang ingin dicapai dituangkan ke dalam beberapa kegiatan pembelajaran. Peneliti melibatkan guru yang mengajar mata pelajaran administrasi server sebagai ahli karena mengetahui secara detail kegiatan pembelajaran yang dilakukan. Penilaian hasil dari uji ahli isi dihitung dengan Rumus Gregory. Gregory menurut (Candiasa, I. M, 2010) mengembangkan teknik dalam pengujian isi yang sudah dikuantitatifkan. Mekanisme perhitungan pengujian validitas isi menurut Gregory adalah sebagai berikut.

a. Para pakar yang dipercaya menilai instrument melakukan penilaian instrument perbutir.

b. Pengelompokan skala, sesuai dan tidak sesuai.

c. Hasil penilaian para pakar ditabulasi silang, misalnya untuk dua penilai seperti pada tabel 3

\begin{tabular}{|c|c|c|c|}
\hline & \multicolumn{2}{|c|}{ PENILAI 1} \\
\hline & & Tidak Sesuai & Sesuai \\
\hline \multirow[b]{2}{*}{ PENILAI 2} & Tidak Sesuai & (A) & (B) \\
\hline & Sesuai & (C) & (D) \\
\hline
\end{tabular}

Perhitungan validitas isi dengan rumus

Validitas Isi $=\frac{D}{\mathbf{A}+\mathbf{B}+\mathbf{C}+\mathbf{D}}=$

Keterangan :

$\mathrm{A}=$ Sel yang menunjukkan ketidaksetujuan

antara kedua penilai

$B$ dan $C=$ Sel yang menunjukkan perbedaan

pandangan antara penilai

$\mathrm{D}=$ Sel yang menunjukkan

persetujuan valid

antara kedua penilai.
Untuk melihat tingkat pencapaian kriteria validitas isi dapat dilihat pada Tabel 4 berikut.

\begin{tabular}{|c|c|}
\hline Koefesien Validitas & Tingkat Validitas \\
\hline $0,91-1,00$ & Sangat Tinggi \\
\hline $0,71-0,90$ & Tinggi \\
\hline $0,41-0,70$ & Cukup \\
\hline $0,21-0,40$ & Rendah \\
\hline $0,00-0,20$ & Sangat Rendah \\
\hline
\end{tabular}

2. Validasi Ahli Desain

Validasi desain dilakukan oleh ahli desain pembelajaran. Dalam hal ini akan dilakukan validasi terhadap strukturisasi penjabaran materi. Untuk validasi desain pembelajaran dilakukan dengan menggunakan angket. Dimana melibatkan orang yang ahli dalam bidang desain pembelajaran. Penilaian hasil dari uji ahli desain pembelajaran dihitung dengan Rumus Gregory (Gregory, 2000).

3. Validasi Ahli Media

Validasi media dilakukan oleh ahli media pembelajaran. Dalam hal ini akan dilakukan validasi terhadap ketepatan tata letak bentuk dari penulisan modul. Untuk validasi media pembelajaran dilakukan dengan menggunakan angket, dimana melibatkan orang yang ahli dalam bidang media pembelajaran. Penilaian hasil dari uji ahli media pembelajaran dihitung dengan Rumus Gregory (Gregory, 2000).

4. Validasi Perorangan

Validasi perorangan dilakukan oleh kelas yang mendapat mata pelajaran administrasi server.Validasi perorangan dilakukan dengan menggunakan angket. Rumus yang digunakan menghitung persentase masingmasing subyek menurut (Tegeh \& Kirna, 2010) sebagai berikut.

$$
\begin{aligned}
& \text { Persentase }=\sum \frac{\text { (Jawaban } \times \text { bobot tiap pilihan) }}{n \times \text { bobot tertingef }} \times 100 \% \ldots \\
& \text { Keterangan : } \Sigma=\text { jumlah } \\
& \qquad n=\text { jumlah seluruh item angket }
\end{aligned}
$$

Selanjutnya, untuk menghitung persentase keseluruhan subjek digunakan rumus : 
Persentase $=(F: N)$

Keterangan: $F$ = jumlah persentase keseluruhan subjek

$$
\mathrm{N} \text { = banyak subjek }
$$

Untuk dapat memberikan makna dan pengambilan keputusan maka digunakan ketetapan terhadap hasil review dan uji coba produk seperti pada Tabel 5.

\begin{tabular}{|l|l|l|}
\hline $\begin{array}{c}\text { Tingkat Pencapaian } \\
(\%)\end{array}$ & \multicolumn{1}{|c|}{ Kualifikasi } & \multicolumn{1}{|c|}{ Keterangan } \\
\hline $90 \leq \mathrm{P} \leq 100$ & Sangat baik & Tidak perlu direvisi \\
\hline $75 \leq \mathrm{P}<90$ & Baik & Sedikit direvisi \\
\hline $65 \leq \mathrm{P}<75$ & Cukup & Direvisi secukupnya \\
\hline $55 \leq \mathrm{P}<65$ & Kurang & Banyak hal yang direvisi \\
\hline $\mathrm{P}<55$ & Sangat kurang & Diulangi membuat produk \\
\hline
\end{tabular}

5. Validasi Kelompok Kecil

Validasi kelompok kecil dilakukan dengan menggunakan angket. Rumus yang digunakan menghitung persentase kelompok kecil adalah rumus (Tegeh \& Kirna, 2010)

\section{Validasi Lapangan}

Tujuan akhir dalam pengembangan produk e-modul ini adalah untuk mengetahui respon guru dan siswa terhadap pengembangan e-modul dalam pembelajaran administrasi server. Untuk melakukan perhitungan analisis data respon guru dan siswa maka didasarkan pada rata-rata kelas $(x \overline{)}$ dari respon guru dan siswa, Mi, SDi. Menurut (Nurkancana, \& Sunartana, 1992) rata-rata kelas dari skor respon guru dan siswa dihitung menggunakan rumus:

$$
\bar{x}=\frac{\sum x}{N}
$$

\footnotetext{
Keterangan:

$\bar{x}=$ Rata - rata kelas untuk skor respon guru dan siswa

$\sum x=$ Jumlah skor respon guru siswa

$\dot{N}=$ Banyaknya guru dan siswa
}

Sedangkan untuk mencari mean ideal (Mi) dan standar deviasi ideal (SDi) digunakan rumus sebagai berikut :

$M i=\frac{1}{2}($ skor maksimal ideal + skor terendah ideal $)$.

$S D i=\frac{1}{6}($ skor tertinggi ideal + skor terendah ideal $)$.

Data respon siswa terhadap penerapan model pembelajaran Discovery Learning kemudian digolongkan kedalam kategori seperti pada Tabel 6 .

\begin{tabular}{|c|l|l|}
\hline No. & \multicolumn{1}{|c|}{ Interval } & \multicolumn{1}{|c|}{ Kategori } \\
\hline 1 & $\mathrm{Mi}+1,5 \mathrm{SDi} \leq \bar{x}$ & Sangat Positif \\
\hline 2 & $\mathrm{Mi}+0,5 \mathrm{SDi} \leq \bar{x}<\mathrm{Mi}+1,5 \mathrm{SDi}$ & Positif \\
\hline 3 & $\mathrm{Mi}-0,5 \mathrm{SDi} \leq \bar{x}<\mathrm{Mi}+0,5 \mathrm{SDi}$ & Kurang Positif \\
\hline 4 & $\mathrm{Mi}-1,5 \mathrm{SDi} \leq \bar{x}<\mathrm{Mi}-1,5 \mathrm{SDi}$ & Negatif \\
\hline 5 & $\bar{x}<\mathrm{Mi}-1,5 \mathrm{SDi}$ & Sangat Negatif \\
\hline
\end{tabular}

\section{PEMBAHASAN}

Pengembangan e-modul mata pelajaran administrasi server memiliki tujuan untuk membantu penambahan sumber belajar, media pembelajaran, meningkatkan kemandirian siswa dan diharapkan dapat meningkatkan pemahaman materi pelajaran administrasi server selama proses belajar mengajar di kelas. Berdasarkan hasil observasi awal yang dilakukan di SMK TI Bali Global Singaraja, dapat diketahui bahwa media pembelajaran yang digunakan belum sesuai dengan tuntutan kemajuan arus informasi yang memanfaatkan teknologi informasi dan komunikasi sebagai sistem informasi pendidikan. Media yang digunakan saat proses pembelajaran berupa power point yakni materi yang tersampaikan hanya inti dari materi tersebut. Bahkan sekolah telah memiliki fasilitas seperti wifi yang tersedia di beberapa titik di wilayah sekolah yang memungkinkan pembelajaran berbantu media pembelajaran. Secara umum sekolah tersebut memiliki SDM yang baik dalam hal ini guru memiliki kemampuan dalam bidang teknologi, informasi dan komunikasi (TIK). SDM yang didukung dengan fasilitas yang ada sebenarnya memiliki kemampuan mengembangkan media pembelajaran. Hal ini 
dikarenakan guru memiliki jadwal mengajar yang padat, mengejar targer kurikulum serta guru diwajibkan membuat persiapan mengajar. Selain itu siswa juga masih terlalu bergantung pada materi yang diberikan oleh guru di kelas serta siswa kurang mampu mencari dan menemukan solusi secara mandiri sesuai dengan tuntutan Kurikulum 2013. Permasalahan ini disebabkan oleh ketidaktahuan siswa mencari sumber belajar yang tepat dan sumber belajar yang tersusun secara terstruktur. Hal ini tentu berdampak bagi siswa yang dapat menyebabkan siswa menjadi kurang aktif, tidak mandiri sehingga berpengaruh terhadap kurangnya tingkat pemahaman peserta didik serta pembelajaran cenderung berpusat pada guru, hal ini sangat berbanding terbalik dengan penerapan kurikulum 2013 yang mengutamakan kegiatan pembelajaran berpusat pada siswa (student center).

Selain itu pengembangan e-modul mata pelajaran administrasi server menggunakan model Discovery Learning yang bertujuan untuk membuat peserta didik aktif, dan mandiri dalam proses belajarnya, bertanggung jawab dan berinisiatif untuk mengenali kebutuhan belajarnya, menemukan sumber-sumber informasi, untuk dapat menjawab kebutuhannya, membangun serta mempresentasikan pengetahuannya berdasarkan kebutuhan serta sumber-sumber yang ditemukan. Sesuai dengan tahapan pada desain penelitian yang digunakan model pengembangan PLOMP, tahapan pertama yang dilakukan adalah Investigasi Awal (Prelimenary Investigation). Kegiatan yang dilakukan pada tahap investigasi awal adalah mengumpulkan dan menganalisis informasi, mendefinisikan masalah dan merencanakan kegiatan selanjutnya. Pada tahapan ini juga dilakukan analisis terhadap (1) analisis tujuan dan karakteristik bidang studi, (2) analisis sumber belajar, (3) analisis karakteristik siswa. Pada tahap analisis tujuan dan karakteristik bidang studi peneliti melakukan analisis mengenai tujuan dari mata pelajaran Administrasi Server, dimana tujuan dari mata pelajaran ini adalah memberikan pemahaman tentang konsep dan praktek mengenai pengontrolan atau pengelolaan akses terhadap jaringan dan sumber daya yang terdapat di dalamnya serta karakteristik dari mata pelajaran Administrasi Server adalah bersifat pemahaman konsep dan praktikum. Pada tahap analisis sumber belajar peneliti melakukan proses analisis mengenai sumber belajar yang digunakan pebelajar dalam proses pembelajaran baik berupa modul, maupun sumber lain berupa internet. Berdasarkan observasi awal, peneliti memberikan angket yang disebar kepada siswa dan melakukan wawancara kepada guru mata pelajaran. Selama ini sumber belajar yang digunakan oleh guru dan siswa yaitu materi yang didapatkan dari internet dan berupa power point yang diberikan oleh guru. Maka dari itu peneliti akan mengembangkan sebuah media pembelajaran berupa e-modul dengan menggunakan platform schoology. Schoology merupakan sebuah layanan gratis yang menggunakan konsep pengelolaan pembelajaran sosial yang dikhususkan untuk membangun lingkungan belajar online yang aman untuk berbagi informasi serta fitur-fitur atau konten pendidikan baik berbentuk tulisan, file dan link yang dapat dibagikan baik guru maupun siswa. Pada analisis karakteristik siswa peneliti menganalisis karakteristik dari pebelajar yaitu siswa kelas X TKJ di SMK TI Bali Global Singaraja. Untuk mengetahui karakteristik siswa, peneliti melakukan observasi dengan menyebar angket ke siswa. Berdasarkan hasil analisis angket tersebut didapat bahwa siswa dalam mempelajari mata pelajaran Administrasi Server cenderung mengandalkan materi dari guru karena sulit mencari materi yang sesuai dengan tuntutan kurikulum. Selain itu model pembelajaran yang selama ini digunakan masih belum efektif karena menciptakan situasi belajar yang masih berpusat pada guru sehingga siswa terkesan kurang aktif dalam kegiatan pembelajaran. Dari hasil analisis tersebut dapat disimpulkan bahwa siswa tersebut cenderung kurang aktif, oleh karena itu peneliti dalam mengembangkan e-modul menggunakan model pembelajaran Discovery Learning karena model pembelajaran ini menuntun siswa untuk menemukan konsep melalui serangkaian data atau informasi yang diperoleh melalui pengamatan atau percobaan.

Tahapan kedua adalah tahap desain (design) meliputi menentukan desain rencana pelaksanaan pembelajaran (RPP), menyusun kerangka berpikir, menentukan komponen modul, 
konsep penyampaian dan pengorganisasian materi, merancang jenis tugas yang diberikan, soal evaluasi, gambar, serta contoh-contoh. Pada tahap desain Rencana Pelaksanaan Pembelajaran (RPP) dimaksudkan guna untuk membantu dalam penyusunan RPP dalam implementasi produk pada proses pembelajaran, desain dari RPP ini mengikuti format penulisan RPP kurikulum 2013 sesuai dengan permendikbud nomor 103 tahun 2014. Pada tahap desain pengembangan modul peneliti membuat rancangan dan menyusun draft modul cetak yang sesuai dengan kompetensi dasar, indikator dan tujuan pembelajaran. Pada tahap desain pengembangan e-modul peneliti melakukan pengembangan rancangan konten yang akan ditampilkan pada e-modul dari mata pelajaran Administrasi Server.

Tahapan ketiga adalah tahap realisasi (realization/contruction). Tahapan ini sebagai lanjutan kegiatan pada tahap desain. Pada tahap ini dihasilkan prototipe 1 sebagai realisasi hasil perancangan modul Pada tahap ini dilakukan pengembangan sistem seperti membuat hak akses masuk ke halaman mata pelajaran, mengatur tampilan kegiatan pembelajaran, menerapkan modul cetak ke sistem e-modul, mengintegrasikan fitur Schoology pada e-modul meliputi penerapan hasil modul ke dalam platform schoology hingga menjadi produk akhir berupa emodul. Pengembangan pada fitur schoology disesuaikan dengan kerangka modul yang digunakan dan berisikan implementasi tahapan discovery learning pada e-modul. Selain itu peneliti mengembangkan video pembelajaran pada kegiatan pembelajaran tertentu yang nantinya video pembelajaran tersebut dijadikan sumber belajar bagi siswa.

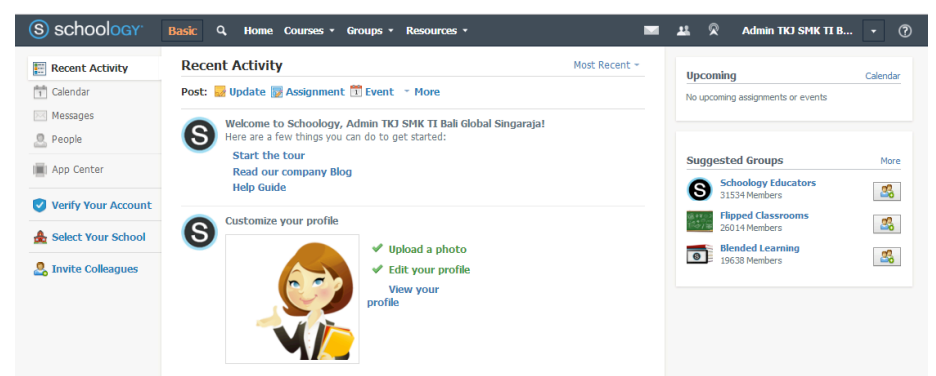

Tahap keempat adalah Test, Evaluasi, Revisi (Test, Evaluation, Revision), yang dilakukan dengan menguji coba e-modul sesuai dengan peran dan fungsinya dalam proses pembelajaran untuk mengetahui sejauh mana manfaat produk yang dikembangkan. Tahapan uji coba dimulai dari review para ahli, kemudian dilanjutkan dengan uji coba perorangan, kelompok kecil, dan uji lapangan. Uji ahli yang pertama dilakukan adalah uji ahli isi pembelajaran. Uji ahli ini bertujuan untuk mengetahui isi yang terkandung di dalam e-modul apakah sudah sesuai dengan konsep pengetahuan atau indikator yang ingin dicapai. Setelah selesai melakukan uji ahli isi, kemudian dilanjutkan dengan uji ahli desain. Uji Ahli desain ini bertujuan untuk mendapatkan validasi e-modul dari segi desain pembelajaran yang terdapat dalam e-modul mata pelajaran administrasi server. Setelah selesai melakukan uji ahli media pembelajaran kemudian dilanjutkan dengan uji media pembelajaran. Uji media pembelajaran ini bertujuan untuk mendapatkan validasi dari segi tampilan dan struktur modul yang disajikan dalam e-modul administrasi server.

Hasil penilaian ahli isi dengan menggunakan uji gregory berdasarkan angket pada siklus I menunjukkan bahwa tingkat pencapaian dari emodul adalah "TINGGI" dan layak untuk dilanjutkan. Hal tersebut mengindikasikan bahwa materi pelajaran yang diimplementasikan dalam e-modul sudah relevan untuk digunakan dalam pembelajaran administrasi server. Materi pelajaran yang memadukan sajian materi dari beberapa sumber buku sebagai referensi pembelajaran dinyatakan valid dan sudah sesuai dengan indikator dan tujuan pembelajaran pada silabus administrasi server. Karakteristik materi pelajaran administrasi server yang cenderung pemahaman konsep dan praktikum, pada emodul sudah dipaparkan dengan bantuan visualisasi melalui gambar dan video sehingga memudahkan pemahaman materi oleh siswa. Hasil angket uji ahli isi pembelajaran pada siklus II berupa revisi uji ahli isi pembelajaran pada siklus I dipaparkan pada lampiran berapa

Hasil penilaian ahli desain pembelajaran dengan menggunakan uji gregory berdasarkan angket pada siklus I menunjukkan bahwa tingkat pencapaian dari e-modul adalah "SANGAT TINGGI" dan layak untuk dilanjutkan. Hal tersebut mengindikasikan bahwa penerapan model 
pembelajaran dicovery learning dalam e-modul layak untuk digunakan dalam pembelajaran administrasi server. Melalui penerapan langkahlangkah model discovery learning dalam pembelajaran membuat siswa menjadi lebih aktif untuk menggali pengetahuannya dan membuat siswa menjadi lebih mandiri dalam proses belajar mengajar. Masukan ahli desain seperti memaparkan materi sesuai dengan karakteristik dari peserta didik, dalam pemberian rangsangan dapat menambahkan gambar sehingga siswa mudah dalam melakukan identifikasi masalah dan menyusun hipotesis, memperbaiki tata tulis dan buatkan buku panduan siswa serta RPP dan rublik penilaian agar diupload di schoology telah dilakukan revisi. Hasil angket uji ahli desain pembelajaran pada siklus II berupa revisi uji ahli desain pembelajaran pada siklus I dipaparkan pada lampiran berapa

Hasil penilaian ahli media pembelajaran yang terdiri dari penggunaan bahasa dan keterbacaan, grafis, desain tampilan e-modul, efektivitas, dan media yang dikembangkan dalam e-modul administrasi server telah dinyatakan "SANGAT TINGGI" dan layak untuk dilanjutkan. Media pembelajaran dalam e-modul yang disajikan dalam bentuk teks, gambar, animasi, ataupun video disajikan dengan tepat dan jelas, sehingga siswa dengan mudah dapat belajar dan memahami mata pelajaran administrasi server. Hasil penilaian ahli media mengindikasikan bahwa produk e-modul yang sudah dikembangkan layak untuk digunakan dalam pembelajaran administrasi server. Masukan dari evaluasi ahli media seperti timing pengerjaan agar diatur otomatis oleh sistem, menggunakan font yang lebih ringan yaitu menggunakan font Calibri, serta melengkapi video untuk kegiatan belajar yaitu kegiatan pembelajaran 4 dan kegiatan pembelajaran 5 telah dilakukan revisi. Hasil angket uji ahli media pembelajaran pada siklus II berupa revisi uji ahli media pembelajaran pada siklus I dipaparkan pada lampiran berapa

Langkah selanjutnya yaitu melakukan uji perorangan, uji kelompok kecil, uji lapangan, uji respon guru, dan uji respon siswa. Subjek uji perorangan adalah tiga orang siswa kelas XI TKJ didasarkan pada prestasi mereka yaitu 1 prestasi tinggi, 1 dengan prestasi sedang, dan 1 dengan prestasi rendah. Hasil uji coba perorangan terhadap produk pengembangan e-modul termasuk dalam kategori "BAIK" dan layak untuk dilanjutkan. Hasil penilaian uji coba perorangan mengindikasikan bahwa produk e-modul yang sudah dikembangkan layak untuk digunakan dalam pembelajaran administrasi server. Berdasarkan pengamatan langsung dan wawancara dengan guru pengajar administrasi server, responden uji coba perorangan ini adalah siswa kelas XI yang sudah menguasai pengoperasian komputer dasar namun belum menguasai penggunaan platform schoology, sehingga ketika dilakukan uji coba siswa masih perlu beradaptasi dengan penggunaan e-modul dalam pembelajaran. Solusi pada kegiatan uji coba perorangan ini dilakukan peneliti dengan mengarahkan siswa untuk membaca tutorial pengguna yang sudah terdapat pada e-modul dan mengajarkan cara penggunaannya.

Setelah uji perorangan selesai dan direvisi, maka dilanjutkan dengan uji kelompok kecil. Uji kelompok kecil dilakukan oleh dua belas orang siswa kelas XI TKJ. Hasil uji coba kelompok kecil terhadap produk pengembangan e-modul termasuk dalam kategori "BAIK" dan layak untuk dilanjutkan. Hasil penilaian uji coba lapangan mengindikasikan bahwa produk e-modul yang sudah dikembangkan layak untuk digunakan dalam pembelajaran administrasi server. Pada uji coba kelompok kecil terdapat beberapa hal yang menjadi penyebab siswa belum mengerti pengoperasian e-modul berdasarkan pengamatan di lapangan yaitu siswa belum paham penggunaan e-modul dengan menggunakan platform schoology dengan baik, selama ini metode pembelajaran yang dilakukan siswa adalah mendengarkan penjelasan dari guru sehingga ini merupakan pengalaman awal menggunakan pembelajaran berbasis komputer dengan menggunakan e-modul, sehingga membutuhkan penyesuaian dan penjelasan lebih lengkap tentang e-modul. Namun beberapa temuan tersebut sudah dicoba diatasi oleh peneliti dengan mendampingi siswa secara langsung dalam pengoperasian e-modul dan penggunaan tutorial pengoperasian e-modul. 


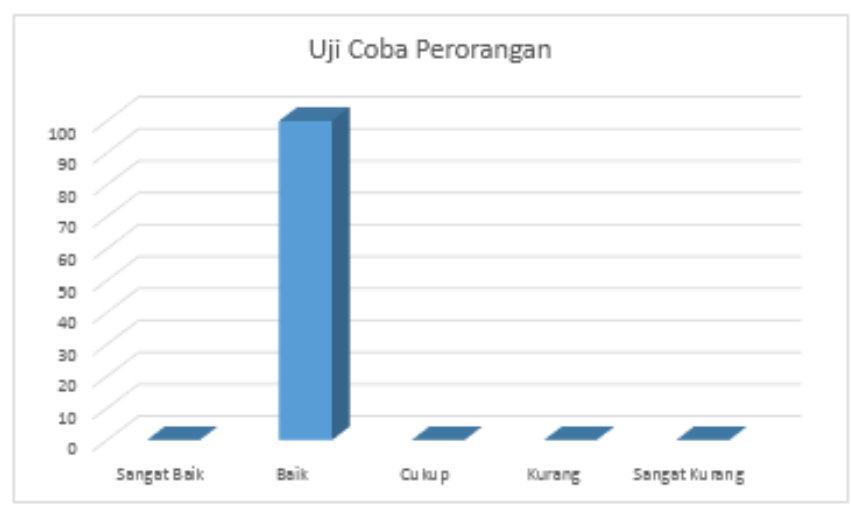

Setelah uji coba kelompok kecil selesai dilanjutkan dengan uji lapangan yang dilakukan oleh dua puluh orang siswa kelas XI TKJ SMK TI Bali Global Singaraja. Hasil uji coba lapangan terhadap produk pengembangan e-modul termasuk dalam kategori "BAIK" dan layak untuk dilanjutkan. Hasil penilaian uji coba lapangan mengindikasikan bahwa produk e-modul yang sudah dikembangkan layak untuk digunakan dalam pembelajaran administrasi server. Berdasarkan temuan di lapangan, penggunaan emodul dalam proses kegiatan belajar mengajar di kelas dapat membantu siswa memahami materi lebih cepat, tanggap, aktif serta meningkatkan interaksi antar guru dan siswa. Melalui isi materi yang disajikan dalam bentuk teks, gambar, dan video dalam e-modul siswa lebih mudah memahami materi dan sangat membantu dalam proses pengumpulan data. Keberhasilan model pembelajaran discovery learning untuk meningkatkan aktivitas belajar siswa disebabkan oleh penerapan model discovery learning yang mampu menumbuhkembangkan keaktifan siswa serta kemandirian siswa dalam kegiatan belajar mengajar di kelas, dalam hal ini sangat sesuai dengan teori belajar kognitivisme. Penerapan teori belajar kognitivisme dalam pembelajaran administrasi server menggunakan model discovery learning diwujudkan dalam bentuk pembelajaran yang berpusat pada siswa (student centre). Bentuk pembelajaran tersebut terbukti siswa mampu belajar berpikir analisis dan mencoba memecahkan sendiri masalah yang dihadapi. Dalam hal ini siswa mendapatkan pengetahuan baru, berfikir untuk menyelesaikan masalah, mengembangkan ide, membuat keputusan serta menemukan konsep melalui serangkaian data atau informasi yang diperoleh melalui pengamatan atau percobaan sebelumnya.

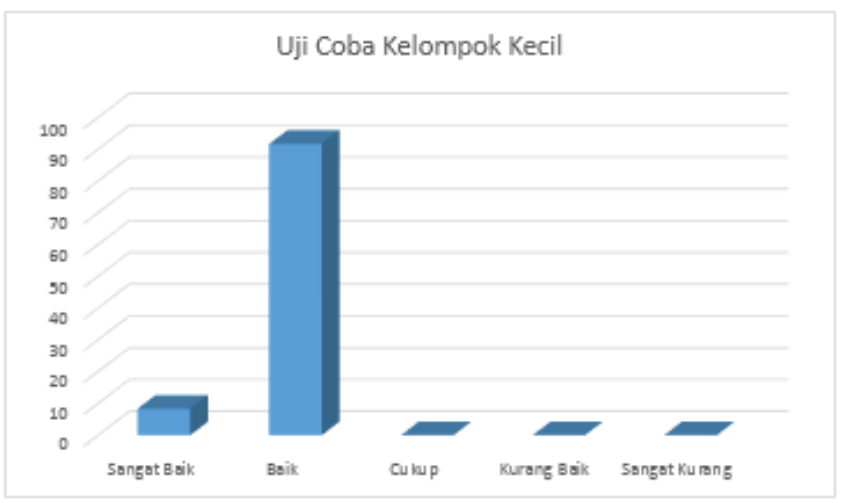

Setelah hasil uji lapangan selesai dilakukan, selanjutnya dilakukan pengambilan respon guru terhadap pengembangan e-modul pada mata pelajaran administrasi server. Hasil repon guru terhadap produk pengembangan e-modul termasuk dalam kategori "POSITIF". Proses uji selanjutnya dilakukan dengan pengambilan respon siswa. Subjek uji coba respon siswa adalah terdiri dari 20 orang siswa kelas XI TKJ yang telah belajar menggunakan e-modul. Hasil respon siswa terhadap produk pengembangan emodul termasuk dalam kategori "POSITIF". Berdasarkan hasil respon guru dan siswa dapat dikategorikan membantu siswa dalam memahami mata pelajaran administrasi server dan berhasil mengatasi permasalahan tidak adanya modul ajar.

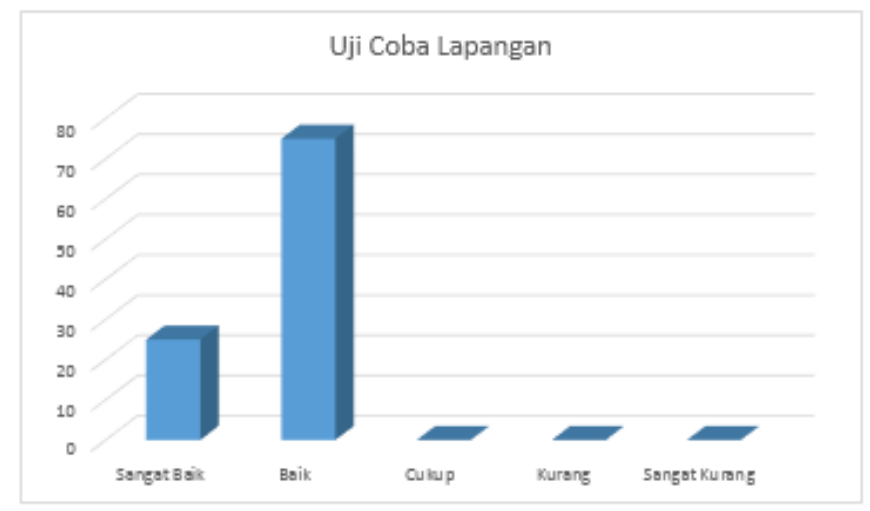

Berdasarkan pembahasan di atas, penilaianpenilaian yang dilakukan oleh ahli isi, ahli desain pembelajaran, ahli media, uji coba perorangan, uji coba kelompok kecil, uji lapangan, maupun 
hasil respon guru dan siswa termasuk dalam kategori baik dan mendapat respon positif. Berdasarkan penilaian tersebut, secara garis besar pengembangan e-modul berbasis model pembelajaran discovery learning pada mata pelajaran administrasi server untuk siswa kelas $X$ TKJ di SMK TI Bali Global Singaraja telah menunjukkan adanya keberhasilan dan layak digunakan sebagai sumber belajar untuk siswa kelas X TKJ di SMK TI Bali Global Singaraja. Hal ini didukung pula dengan beberapa pernyataan siswa yaitu keberadaan e-modul administrasi server sangat membantu dalam proses pembelajaran, e-modul membuat siswa lebih antusias dalam belajar administrasi server, maupun memudahkan siswa memahami materi lebih cepat dan sangat efektif dalam pelajaran. Melalui penerapan e-modul administrasi server ini diharapkan dapat membantu guru selama proses pembelajaran dan masalah selama proses pembelajaran terkait sumber belajar mampu teratasi, serta mampu membuat peserta didik aktif, mandiri dalam proses belajarnya, bertanggung jawab dan berinisiatif untuk mengenali kebutuhan belajarnya, menemukan sumber-sumber informasi untuk dapat menjawab kebutuhannya, membangun dan mempresentasikan pengetahuannya berdasarkan kebutuhan serta sumber-sumber yang ditemukan

Hasil penelitian e-modul pada mata pelajaran administrasi server ini sejalan dengan (Baskara, 2017) yaitu Pengembangan E-Modul Berbasis Model Pembelajaran Discovery Learning Pada Mata Pelajaran "Sistem Komputer" Untuk Siswa Kelas X Multimedia SMK Negeri 3 Singaraja yaitu sama-sama memperoleh penilaian layak pada uji coba perorangan, kelompok kecil, dan lapangan serta mendapat respon positif pada uji respon guru dan siswa. Hasil penelitian ini juga sejalan dengan penelitian Fausih dan Danang (2015) tentang Pengembangan E-modul Mata Pelajaran Produktif Pokok Bahasan "Instalasi Jaringan LAN" Untuk Siswa Kelas XI Jurusan Teknik Komputer Jaringan di SMK Negeri 1 Labang Bangkalan Madura yaitu sama-sama memperoleh penilaian layak untuk diimplementasikan sebagai media pembelajaran pada uji coba perorangan, kelompok kecil, dan lapangan serta mendapat respon positif pada uji respon guru dan siswa.
E-modul administrasi server yang diterapkan di SMK TI Bali Global Singaraja dengan subjek uji coba yaitu siswa kelas XI TKJ dan guru pengajar administrasi server di jurusan TKJ ini memiliki beberapa kelebihan dan kendala yang ditemukan, adapun kelebihan dari e-modul administrasi server dengan menggunakan platform schoology yang ditemukan yaitu. 1) Emodul administrasi server memudahkan siswa dalam mencari sumber belajar yang sesuai dengan tuntutan kurikulum 2013, 2) E-modul administrasi server meningkatkan kemandirian dan kerjasama antar siswa dalam belajar karena menggunakan model pembelajaran yang sesuai dengan kurikulum yang berlaku saat ini yaitu model pembelajaran discovery learning, 3) Emodul menambah semangat siswa dalam belajar administrasi server, karena pembelajaran dengan menggunakan e-modul membawa siswa pada suasana pembelajaran baru yang belum pernah siswa dapatkan sebelumnya sehingga rasa ingin tahu siswa dalam belajar dengan menggunakan e-modul membuat mereka menjadi lebih bersemangat dalam belajar. Sedangkan kendala yang ditemukan selama melakukan uji coba emodul administrasi server yaitu siswa belum menguasai penggunaan e-modul dengan menggunakan platform schoology, sehingga ketika dilakukan uji coba siswa masih perlu beradaptasi dengan penggunaan e-modul dalam pembelajaran. Selain itu terdapat kelemahan pada schoology yaitu fitur group yang tidak terintegrasi dengan course tertentu, namun fitur group tesedia secara umum diluar course, sehingga sebelum siswa akan melaksanakan diskusi pada fitur group maka siswa harus keluar dari course. Jika siswa sudah menyelesaikan diskusi pada fitur group maka siswa masuk kembali pada suatu course untuk mengupload hasil diskusi yang telah dilakukan. Hal tersebut menjadi rumit dan menyebabkan siswa merasa kesulitan akan melaksanakan diskusi kelompok dan mengupload hasil diskusi. Solusi pada kegiatan uji coba ini dilakukan peneliti dengan mengarahkan siswa untuk membaca tutorial pengguna yang sudah terdapat pada e-modul dan mendampingi siswa secara langsung. 


\section{SIMPULAN}

Berdasarkan hasil penelitian dan pembahasan pada penelitian Pengembangan E-Modul Pembelajaran Administrasi Server Kelas X TKJ Di SMK TI Bali Global Singaraja, maka penulis dapat menarik kesimpulan sebagai berikut: (1) Hasil rancangan dan realisasi Pengembangan EModul Pembelajaran Administrasi Server Kelas X TKJ di SMK TI Bali Global Singaraja menggunakan tahapan model discovery learning sudah dinyatakan berhasil diterapkan. Hal ini dapat dilihat dari rata-rata persentase berdasarkan hasil pengujian yang telah dilakukan. Secara umum siswa terlihat antusias dan lebih aktif selama proses pembelajaran berlangsung.(2) Respon guru terhadap Pengembangan E-Modul Pembelajaran Administrasi Server Kelas X TKJ di SMK TI Bali Global Singaraja didapatkan rata-rata sebesar 43. Jika dikonversikan ke dalam tabel kriteria penggolongan respon maka hasilnya termasuk dalam kategori positif. Sedangkan untuk respon siswa terhadap pengembangan e-modul administrasi server memperoleh rata-rata sebesar 64,50. Jika dikonversikan ke dalam tabel kriteria penggolongan respon maka hasilnya termasuk dalam kategori positif.

Berdasarkan pengamatan penulis, terdapat beberapa hal yang dapat dijadikan bahan pertimbangan untuk ditindak lanjuti : (1) Bagi pengembang e-modul selanjutnya agar dapat mengatur e-modul lebih user friendly atau mudah digunakan oleh pengguna yang masih belum terbiasa dengan pembelajaran berbasis komputer. Maka dari itu untuk mencegah terjadinya permasalahan yang sama, diharapkan untuk peneliti selanjutnya agar memperkenalkan e-modul terlebih dahulu serta melatih siswa dalam menggunakan e-modul sebelum melakukan uji coba perorangan, kelompok kecil dan lapangan. (2) Pengembangan e-modul pada mata pelajaran administrasi server ini hanya dilakukan uji coba pada kegiatan belajar 1, jadi diharapkan untuk peneliti selanjutnya agar dapat melakukan uji coba secara keseluruhan dari emodul ini. (3) Produk e-modul berbasis model pembelajaran discovery learning pada mata pelajaran administrasi server untuk siswa kelas $X$ TKJ di SMK TI Bali Global Singaraja yang dikembangkan belum sampai pada tahap implementasi . Oleh karena itu, perlu diadakan pengkajian lebih lanjut mengenai efektivitas penggunaan e-modul berkaitan dengan pengukuran hasil belajar siswa menggunakan emodul ini melalui penelitian eksperimen.

\section{REFERENSI}

[1] Agustini, K. (2013). Pengaruh Penggunaan Simulasi Binary Tree Berbasis CAI Terhada Motivasi Dan Hasil Belajar Matematika Diskrit Mahasiswa Jurusan PTI Undiksha. Jurnal Pendidikan Indonesia.

[2] Ananda, M. (2014). Pengembangan ELearning Berbasis Schoology Pada Mata Pelajaran IPA Kelas VIII di SMP Negeri 1 Seririt. Jurusan Teknologi Pendidikan: Journal Edutech Universitas Pendidikan Ganesha.

[3] Anwar, I. (2010). Pengembangan Bahan Ajar. Bahan Kuliah Onlline. Bandung: Direktori UPI.

[4] Baskara, K. W. (2017). Pengembangan EModul Berbasis Model Pembelajaran Discovery Learning Pada Mata Pelajaran "Sistem Komputer" Untuk Siswa Kelas X Multimedia Smk Negeri 3 Singaraja. Karmapati.

[5] Cecep, K., \& Bambang, S. (2013). Media Pembelajaran Manual dan Digital. Bogor: Penerbit Ghalia Indonesia.

[6] Direktorat Pembinaan Sekolah Menengah Atas. (2008). Petunjuk Teknis Pengembangan Bahan Ajar. Jakarta: Depdiknas.

[7] Djamarah, a. a. (1999). Strategi Belajar Mengajar. Jakarta: Rineka Cipta.

[8] Fausih, M. (2015). Pengembangan Media EModul Mata Pelajaran Produktif Pokok Bahasan Instalasi Jaringan LAN (Local Area Network) untuk Siswa Kelas XI Jurusan Teknik Komputer Jaringan di SMK Negeri 1 Labang Bangkalan Madura.

[9] Fosnot, C. T. (1989). Equiring Teacher Equiring Learners: a Constructivist Appoarch for Teaching. New York: Teacher College Press. 
[10] Gunadharma. (2011). Pengembangan Modul Elektronik sebagai Sumber Belajar Untuk Mata Kuliah Multimedia Design. Jurusan Teknologi Pendidikan, Fakultas IImu Pendidikan, Universitas Negeri Jakarta: Skripsi (tidak diterbitkan).

[11] Hosnan. (2014). Pendekatan Scientific dan Kontektual dalam Pembelajaran Abad 21. Bogor: Ghalia Indonesia.

[12] Irawan, F. C. (2015). Pengembangan EModul Berbasis Android Untuk Mata Pelajaran Manajemen Produksi Pada Siswa Kelas XI Di SMK Negeri 1 Surabaya. Surabaya: Jurnal Mahasiswa Teknologi Pendidikan.

[13] Joyce, B., \& Weil, M. (1980). Models of Teaching. New Jersey: Prentice-Hall. Inc.

[14] Kementerian Pendidikan dan Kebudayaan. (2013). Model Pembelajaran Penemuan (Discovery Learning).

[15] Khabibah. (2006). Pengembangan Model Pembelajaran Matematika dengan Soal Terbuka untuk Meningkatkan Kreatifitas Siswa Sekolah Dasar. Doktoral Universitas Negeri Surabaya.

[16] Kurniasih. (2014). Sukses Mengimplementasikan Kurikulum 2013. Jakarta: Kata Pena.

[17] Mertasari. (2010). Modul Web dengan Pola Insentif untuk meningkatkan Kemampuan Memahamu Materi Bahasa Inggris. Jurnal Pendidikan dan Pengajaran. Jilid 43 Nomor 3.

[18] P. N. (2007). Standar Proses untuk Satuan Pendidikan Dasar dan Menengah.

[19] Pannen. (2001). Penulisan Bahan Ajar. Jakarta: Pusat antar Universitas untuk Peningkatan dan Pengembangan Aktifitas Instruksional Ditjen Dikti Diknas.

[20] Peraturan Pemerintah No.17 pasal 59 . (2010). Pengelolaan dan Penyelenggaraan Pendidikan.

[21] Peraturan Pemerintah Republik Indonesia Nomor 19. (2005). Standar Nasional Pendidikan (SNP).
[22] Plomp, T. (1997). Educational and Training Sistem Design. Enschede: University of Twente.

[23] Poppy, K. d. (2009). Pengembangan Perangkat Pembelajaran Untuk Guru SMP. Jakarta: PPPPTK IPA.

[24] Prastowo, A. (2011). Panduan Kreatif Membuat Bahan Ajar Inovatif . Yogyakarta: DIVA Press.

[25] Putrayasa, I. B. (2011). Studi Penelusuran Miskonsepsi dalam Pembelajaran Tata kalimat dengan Model Konstruktivisme Berpendekatan Inquiri pada Siswa Kelas I SMP Negeri di Kota Singaraja, Kabupaten Buleleng, Provinsi Bali.

[26] Satriawati, H. (2015). Pengembangan EModul Interatif Sebagai Sumber Belajar Elektronika Dasar Kelas X SMKN 3 Yogyakarta.

[27] Slavin, R. E. (2000). Educational Psychoolgy: Theory and Practice. Massachusetts: Allyn and Bacon.

[28] Sugiyono. (2008). Metode Penelitian Kuantitatif, Kualitatif dan R \& D. Bandung: Alfabeta.

[29] Sukardjo, M., \& Komarudin, U. (2010). Landasan Pendidikan: Konsep dan Aplikasinya. Jakarta: Rajawali Pers.

[30] Sungkono, d. (2003). Pengembangan Bahan Ajar. Yogyakarta: FIP UNY.

[31] Syah, M. (2005). Psikologi Belajar. Jakarta: PT Raja Grafindo Persada.

[32] Tasker, R. (1992). Effective Teaching, What Can a Constructivist Vies of Learning Offer? Australian Science Teacher Journal. Vol.38,No 1.

[33] Tegeh, I. M., \& Kirna, I. M. (2010). Metode Penelitian Pengembangan Pendidikan. Singaraja: Undiksha.

[34] Trianto. (2009). Mendesain Model Pembelajaran Inovatif Progresif: Konsep, Landasan, dan Implementasinya pada KTSP. Jakarta: Kencana Prenanda Media Group.

[35] Trianto. (2012). Model Pembelajaran Terpadu: Konsep, Strategi dan Implementasi 
dalam Kurikulum Tingkat Satuan Pendidikan (KTSP). Jakarta: Bumi Aksara.

[36] Vembrianto. (1985). Pengantar Modul. Yogyakarta: Pendidikan Paramita.

[37] Winaya, A. (2016). Pengembangan E-Modul Berbasis Project Based Learning Pada Mata Pelejaran Pemrograman Web Kelas X di SMK Negeri 3 Singaraja. Jurnal Pendidikan Teknologi dan Kejuruan.

[38] Wirawan, A. (2011). Pengembangan Desain Pembelajaran Mobile Learning Management System Pada Materi Pengenalan Komponen Jaringan. Jurnal Penelitian dan Pengembangan Pendidikan 